\title{
Cardiac myxoma with glandular elements: a case report
}

\author{
KC Bibek ${ }^{1}$, Karki Shovana ${ }^{1}$ \\ ${ }^{\prime}$ Department of Pathology, Tribhuvan University teaching hospital, Kathmandu, Nepal.
}

\section{Keywords: \\ Cardiac; \\ Gland; \\ Myxoma}

\begin{abstract}
Cardiac myxoma with glandular elements is extremely rare cardiac myxomas that show glandular differentiation, the pathogenesis of which is unknown. The present case study reports a case of glandular cardiac myxoma. A 21-years-old female presented with left atrial mass which was surgically resected and sent for histopathological examination. Microscopically, there were well formed mucinous glands in a background of cardiac myxoma and hence cardiac myxoma with glandular elements was confirmed. Though rare, it should always be differentiated from metastatic adenocarcinoma.
\end{abstract}

\section{Correspondence:}

Dr. Shovana karki, MBBS, MD

Lecturer, Department of Pathology

Tribhuvan University teaching hospital, Kathmandu, Nepal.

ORCID ID: 0000-0001-5429-2422

Email: shovana_karki@hotmail.com

Reveived : July 6th, 2017 ; Accepted : August 12th, 2017; Published : September 1, 2017

Citation: KC Bibek, Karki S. Cardiac myxoma with glandular elements: A case report. J Pathol Nep. 2017;7:1124-6. doi: 10.3126/jpn.v7i2.18038

Copyright: This is an open-access article distributed under the terms of the Creative Commons Attribution 4.0 International License, which permits unrestricted use, distribution, and reproduction in any medium, provided the original author and source are credited.

\section{INTRODUCTION}

Cardiac myxoma is the most common primary tumour of the heart which is derived from pluripotent mesenchyme and it is characterized by presence of abundant myxoid matrix with embedded "myxoma" cells. ${ }^{1}$ Majority of the patients are within the age range of 30-60 years. The most common site is the left atrium (85-90\% cases) arising from endocardium of the atrial septum near the fossa ovalis. ${ }^{2}$ It occurs sporadically in most of the cases and may also be associated with autosomal dominant myxoma syndrome, in which cases, the recurrence rate is higher. ${ }^{3}$ The clinical presentation is diverse and depends predominantly on the location of the tumour. Rarely, these tumours show glandular component, the incidence rate varying from 2-5\% as stated in different textbooks and series. ${ }^{1}$ Due to its rarity, pertinent aspects such as histology, histochemistry and immunochemistry of glandular cardiac myxoma have not been sufficiently studied. ${ }^{4}$ 


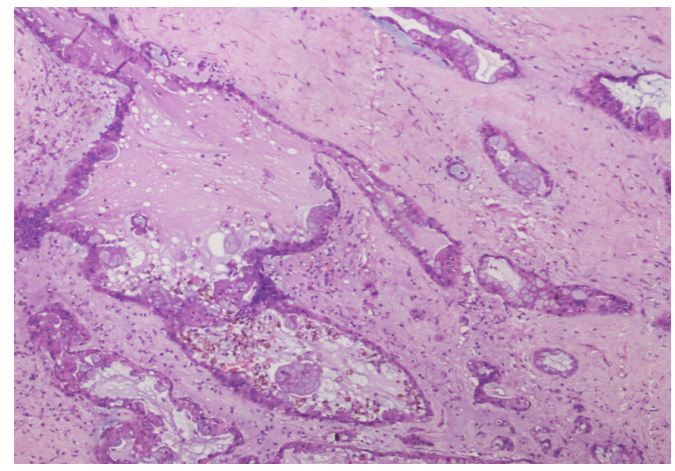

Figure 1: Benign glands in a background of myxoid stroma (HE stain, X40).

\section{CASE REPORT}

A biopsy sample of a 21-years-old female from mass in left atrium after surgical resection was received in Department of Pathology, TUTH, IOM. On gross examination, the specimen consisted of a single piece of gray white to yellow tissue with finger like projections measuring $5 \times 2 \mathrm{~cm}$. Cut section showed cystic spaces. Representative sections were submitted for histopathological examination.

Microscopically, the lesion consisted of plump spindle, ovoid or stellate shaped cells which were either singly scattered or arranged in small groups. These cells had eosinophilic cytoplasm and oval to round nucleus. These cells were embedded with the myxoid matrix. Thick walled blood vessels and hemorrhagic area were also noted. In addition, there were benign looking glands with basally placed nucleus and apical mucin located at the base of the tumour. The glandular cells showed no cytological atypia. No mitosis or necrosis was identified. These features were consistent with a glandular cardiac myxoma, (fig. 1\&2). Immunohistochemical tests were not done as they were not available.

\section{DISCUSSION}

Glandular cardiac myxoma, also known as cardiac myxoma with glandular component is extremely rare; only 39 cases being reported in literature till 2007. ${ }^{5}$ The most common location of cardiac myxoma is left atrium, even though some are occasionally found in the right atrium or ventricles. ${ }^{6}$ Although, most cases of cardiac myxoma occur sporadically, less than $10 \%$ have been reported to occur in association with various syndrome, such as myxoma syndrome, Carney syndrome, NAME syndrome and LAMB syndrome. ${ }^{1,3}$ Those associated with syndrome have higher frequency of multifocal locations and/ or recurrence. ${ }^{1}$

The clinical manifestation is diverse depending upon the location, patient age and size of the tumour. ${ }^{7}$ In a series study done by Pinede et al., almost all patients showed at least 1 or more features of the classic triad: obstructive cardiac signs,

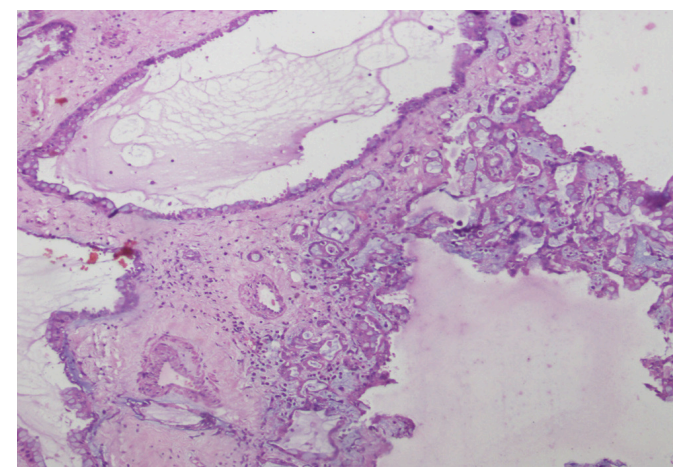

Figure 2: Variable sized glands containing mucin in the lumen (HE stain, X100).

embolic signs or constitutional manifestations. ${ }^{8}$

Grossly, the tumour can be as large as $14 \mathrm{~cm}$ in diameter, sessile or pedunculated and may be ovoid, globular, lobulated or polypoid with multiple papillary fronds. ${ }^{2,3}$ They are usually soft, friable with gelatinous appearance and consistency, some showing cystic change as well. ${ }^{1}$

Microscopic examination shows wellformed glands lined by flattened to columnar epithelium in a typical myxoid matrix. Immunohistochemically, the mucinous glandular lining cells are strongly positive for cytokeratin 7 (CK 7), epithelial membrane antigen and CAM 5.2 and partially positive for calretinin. ${ }^{6,9}$ The combination of histopathological features of the tumour along with immunohistochemistry profiles helps to provide the diagnostic accuracy of glandular cardiac myxoma. ${ }^{8}$

Glandular component of myxoma shows wellformed glands which are lined by cuboidal to columnar epithelium, seen mostly in the base or stalk region. Thus, it is imperative to correctly identify this condition and differentiate from metastatic adenocarcinoma. In metastatic adenocarcinoma, microscopic examination shows atypical glands with frequent mitosis, including abnormal forms and areas of necrosis. ${ }^{5}$

The histogenesis is uncertain. It has been hypothesized that the stromal cells originate from multipotent mesenchyme which has potential for neural and endothelial differentiation and glandular structures represent entrapped foregut rests. ${ }^{10,11}$ Surgical resection is the treatment of choice and prognosis after surgery is usually excellent. ${ }^{12}$

\section{CONCLUSION}

Glandular cardiac myxoma is very rare and it is important to correctly recognize this entity and differentiate it from metastatic adenocarcinoma.

\section{Conflict of Interest: None}




\section{REFERENCES}

1. Sternberg SS. Diagnostic Surgical Pathology. 5 ed. Mills SE, editor. Lippincott Williams \& Wilkins; USA: 2010. p.1208-11.

2. World Health Orgnization Classification of Tumours. TravisWD, Brambilla E, Muller-Hermelink HK, Harris CC, editor. Lyon: IARC; 2004. p.260-3.

3. Fletcher CDM. Diagnostic Histopathology of Tumours. 4 ed. USA: Elsevier; 2013.p. 7-15.

4. Yuan SM. Glandular cardiac myxoma: case report with literature review. Folia morphologica. 2014;73:374-82. Crossref

5. Divya E, Rukhmangadha N, Patnayak R, Chandra A, Murthy HK. Glandular myxoma of left atrium: An uncommon tumor. Heart India. 20161;4:100.

6. Wang Y, Maitland A, Kidd W. Glandular cardiac myxoma. Adv Mod Oncol Res 2016;2:xx-xx; Crossref

7. Burke AP, Virmani R. Cardiac myxoma: a clinicopathologic study. American journal of clinical pathology. 1993;100:671-80. Crossref
8. Pinede L, Duhaut P, Loire R. Clinical presentation of left atrial cardiac myxoma: a series of 112 consecutive cases. Medicine. 2001;80:15972. Crossref

9. Zhang M, Ding L, Liu Y, Xue L. Cardiac myxoma with glandular elements: A clinicopathological and immunohistochemical study of five new cases with an emphasis on differential diagnosis. PathologyResearch and Practice. 2014;210:55-8. Crossref

10. Pucci A, Gagliardotto P, Zanini C, Pansini S, di Summa M, Mollo F. Histopathologic and clinical characterization of cardiac myxoma: review of 53 cases from a single institution. American heart journal. 2000;140:134-8. Crossref

11. Lloreta J, Juanpere N, Riverola A, Dallari D, Ca-as MA, Pijuan L, Baró T, García P, Serrano S. Cardiac myxoma with glandular differentiation: an immunohistochemical and ultrastructural Study. Ultrastructural pathology. 2013;37:77-82. Crossref

12. Hoffmeier A, Sindermann JR, ScheldHH, Martens S. Cardiac tumors-diagnosis and surgical treatment. DtschArztebl Int. 2014;111:205-11. Crossref 